\title{
Effects of Curcumin on Parameters of Myocardial Oxidative Stress and of Mitochondrial Glutathione Turnover in Reoxygenation after 60 Minutes of Hypoxia in Isolated Perfused Working Guinea Pig Hearts
}

\author{
Ermita I. Ibrahim Ilyas, ${ }^{1}$ Busjra M. Nur, ${ }^{1}$ Sonny P. Laksono, ${ }^{1}$ Anton Bahtiar, ${ }^{1}$ \\ Ari Estuningtyas, ${ }^{2}$ Caecilia Vitasyana, ${ }^{2}$ Dede Kusmana, ${ }^{3}$ Frans D. Suyatna, ${ }^{2}$ \\ Muhammad Kamil Tadjudin, ${ }^{4}$ and Hans-Joachim Freisleben ${ }^{5}$ \\ ${ }^{1}$ Department of Physiology, Faculty of Medicine, University of Indonesia, Jakarta 10430, Indonesia \\ ${ }^{2}$ Department of Pharmacology and Therapeutics, Faculty of Medicine, University of Indonesia, Jakarta 10430, Indonesia \\ ${ }^{3}$ National Cardiovascular Center, Harapan Kita Hospital and Department of Cardiology and Vascular Medicine, \\ University of Indonesia, Jakarta 10430, Indonesia \\ ${ }^{4}$ Department of Medical Biology, Faculty of Medicine, University of Indonesia, Jakarta 10430, Indonesia \\ ${ }^{5}$ Medical Research Unit, Faculty of Medicine, University of Indonesia, Jakarta 10430, Indonesia
}

Correspondence should be addressed to Ermita I. Ibrahim Ilyas; ermitailyas@yahoo.com and Hans-Joachim Freisleben; hj.freisleben@t-online.de

Received 24 August 2015; Revised 13 December 2015; Accepted 22 December 2015

Academic Editor: Thérèse Di Paolo-Chênevert

Copyright (C) 2016 Ermita I. Ibrahim Ilyas et al. This is an open access article distributed under the Creative Commons Attribution License, which permits unrestricted use, distribution, and reproduction in any medium, provided the original work is properly cited.

\begin{abstract}
In cardiovascular surgery ischemia-reperfusion injury is a challenging problem, which needs medical intervention. We investigated the effects of curcumin on cardiac, myocardial, and mitochondrial parameters in perfused isolated working Guinea pig hearts. After preliminary experiments to establish the model, normoxia was set at 30 minutes, hypoxia was set at 60 , and subsequent reoxygenation was set at 30 minutes. Curcumin was applied in the perfusion buffer at 0.25 and $0.5 \mu \mathrm{M}$ concentrations. Cardiac parameters measured were afterload, coronary and aortic flows, and systolic and diastolic pressure. In the myocardium histopathology and AST in the perfusate indicated cell damage after hypoxia and malondialdehyde (MDA) levels increased to $232.5 \%$ of controls during reoxygenation. Curcumin protected partially against reoxygenation injury without statistically significant differences between the two dosages. Mitochondrial MDA was also increased in reoxygenation (165\% of controls), whereas glutathione was diminished $(35.2 \%)$ as well as glutathione reductase $(29.3 \%)$, which was significantly increased again to $62.0 \%$ by $0.05 \mu \mathrm{M}$ curcumin. Glutathione peroxidase (GPx) was strongly increased in hypoxia and even more in reoxygenation $(255 \%$ of controls). Curcumin partly counteracted this increase and attenuated GPx activity independently in hypoxia and in reoxygenation, $0.25 \mu \mathrm{M}$ concentration to $150 \%$ and $0.5 \mu \mathrm{M}$ concentration to $200 \%$ of normoxic activity.
\end{abstract}

In memoriam Professor Dr. Guido Zimmer (1932-2014), formerly Johann-Wolfgang-Goethe University Frankfurt am Main,

\section{Introduction}

Ischemia-reperfusion injury causes challenging problems in cardiovascular surgery [1-3]. Hypoxia and reoxygenation as a model for ischemia and reperfusion [4] have mainly been studied in isolated perfused rat hearts. Neely et al. [5] modified the original Langendorff preparation [6] into the working rat heart model, which we used to investigate the 
phenomenon of ischemia-reperfusion injury [7]. Now, we changed the rat heart model into isolated perfused working Guinea pig hearts.

Many chemicals used for cardio protection exert severe unwanted side effects. For this reason, natural and more moderate compounds are screened for their protective efficacy against ischemia-reperfusion injury [8]. Curcumin may be a suitable candidate [9] because it has a wide range of clinical activities [10] and structural similarities to antioxidants, for example, tocopherols and cardio protective compounds like flavonoids.

We present a first set of data about cardio protective effects of curcumin using the perfused isolated working Guinea pig heart model. The aims of this study were to find the appropriate experimental conditions for our model and to investigate effects of curcumin under these experimental conditions. In the future, we intend to use this model for the screening of extracts from Indonesian medicinal plants and to study their effects on hypoxia/ischemiareoxygenation/reperfusion injury.

\section{Materials and Methods}

The complete isolated working heart perfusion device was established and all experiments were conducted at the Department of Physiology, Faculty of Medicine, Universitas Indonesia. Young adult Guinea pigs, aged one year and weighing 300-400 g, were obtained from the Animal Breeding Department of the Agricultural University of Bogor, Indonesia. All substances used (if not indicated differently) were purchased from Merck, Darmstadt, Germany, via their Indonesian subsidiary in Jakarta or from Sigma-Aldrich at highest purity available.

2.1. The Model. The arrangement of the perfusion apparatus had been described and schematically depicted by Deisinger and Freisleben [11]. Each Guinea pig was neck-fractured by rapid cervical dislocation, the heart was excised, and the aorta immediately connected to the aortic cannula of the apparatus and was perfused retrogradely as known from the Langendorff preparation. Subsequently, the perfusion cannula was connected anterogradely to the left atrium for normoxic perfusion with Krebs-Henseleit buffer [12] gassed with carbogen $\left(\mathrm{O}_{2} 95 \% / \mathrm{CO}_{2} 5 \%\right)$. During hypoxia, hearts were perfused with the same buffer gassed with $\mathrm{N}_{2}$ $95 \% / \mathrm{CO}_{2} 5 \%$. In reoxygenation, conditions were readjusted to "normoxia," that is, anterograde perfusion with carbogengassed buffer [7]. Normoxia and reoxygenation lasted $30 \mathrm{~min}$, each, whereas hypoxic perfusion varied from 15 to $60 \mathrm{~min}$.

For perfusion of the myocardium, it is important that the cannulation of the aorta does not disturb the access to the coronary arteries. The perfusate flows back to the right atrium mainly via the sinus coronarius and drops from the heart via the open pulmonary artery and venae cavae into a glass vessel, from where it flows back into the buffer circulation. Coronary flow was measured by the volume of perfusate that dropped per minute from the heart into a graduated glass vessel.

Afterload was measured as the height $(\mathrm{cm})$ of the buffer column, which could be maintained by the aortic pressure.
Aortic flow was determined as the volume $(\mathrm{mL})$ per minute at a fixed afterload of $75 \mathrm{~cm}$ buffer column (Figure 1).

To measure systolic and diastolic pressure and heart rate a Nikon Kohden Polygraph was connected. This device also recorded the electrocardiogram, that is, initial arrhythmias; however, further electrocardiographic records were not in an interpretable quality (not shown). Hence, cardiograms were only used to decide about inclusion-exclusion criteria.

2.2. Experimental Procedures: Preliminary Experiments. We conducted preliminary experiments in order to

(i) set up the model and the sequential course of normoxia, hypoxia, and reoxygenation with 15 or $30 \mathrm{~min}$ of normoxic perfusion, 15, 30, or $60 \mathrm{~min}$ of hypoxia, and subsequent reoxygenation up to $30 \mathrm{~min}$. In these experiments the excised hearts were examined for suitability, that is, stability over the time course in this model,

(ii) determine inclusion-exclusion criteria and find out sensitive parameters for measurements in this model. Afterload was first determined in preliminary experiments and then adjusted to $75 \mathrm{~cm}$ water column in the main experiments (Figure 1),

(iii) find appropriate concentrations of curcumin in this model. We applied $0.25,0.5$, and $1 \mu \mathrm{M}$ concentrations, given into the perfusate at 15 min of normoxia. After a first set of experiments, application of $1 \mu \mathrm{M}$ concentration was discontinued because we did not see dosedependent effects and lower concentrations ( 0.25 and $0.5 \mu \mathrm{M}$ ) were even more effective in our model (not shown).

In our preliminary experiments hematoxylin-eosin staining and histopathological examination were conducted using Olympus light microscope at 1000x magnification and compared to aspartate aminotransferase (AST) measurements. For the latter Merck kit (Cat. number 14829) with solution A containing Tris $\mathrm{HCl} \mathrm{pH} \mathrm{7.8,} \mathrm{L-aspartate,} \mathrm{malate}$ dehydrogenase, and lactate dehydrogenase and solution $\mathrm{B}$ containing 2-oxoglutarate and $\mathrm{NADH}$ was used according to the manufacturer's manual with slight modification. One $\mathrm{mL}$ of solution A was mixed with $0.25 \mathrm{~mL}$ of solution $\mathrm{B}$ and incubated for $30 \mathrm{~min}$. To $1 \mathrm{~mL}$ of this mixture $0.2 \mathrm{~mL}$ of perfusate was added and the absorption measured at $340 \mathrm{~nm}$ in Shimadzu spectrophotometer at 1, 2, and $3 \mathrm{~min}$. In our preliminary experiments, we had tested the volumes needed for measurement of the low AST concentrations in the perfusate. The units per liter perfusate were then correlated to the weight of heart tissue and expressed as $\mathrm{U} \times \mathrm{L}^{-1} \times \mathrm{g}^{-1}$ heart tissue.

In the main experiments, histopathological examination was not continued, because histopathology correlated well with AST measurements and myocardial tissue was rather needed for the isolation of mitochondria and all other experimental procedures.

For statistical evaluation one-way ANOVA was used (normal parametric distribution); for nonparametric evaluation post hoc Tukey and Wilcoxon-Mann-Whitney $U$ tests were 


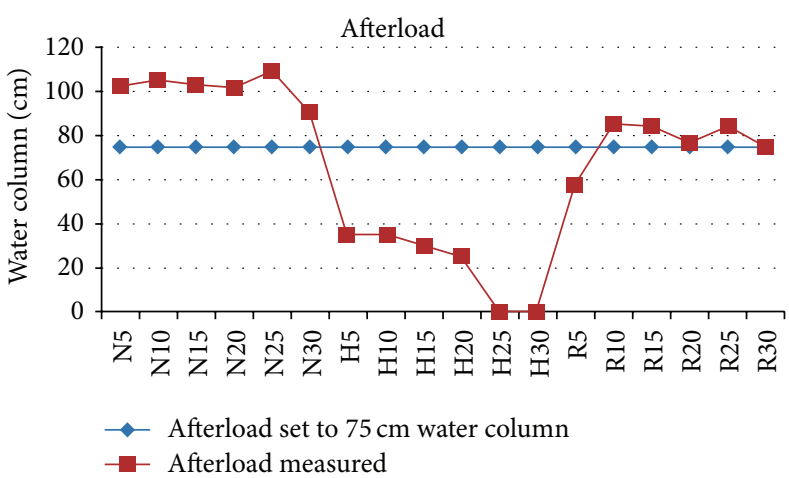

(a)

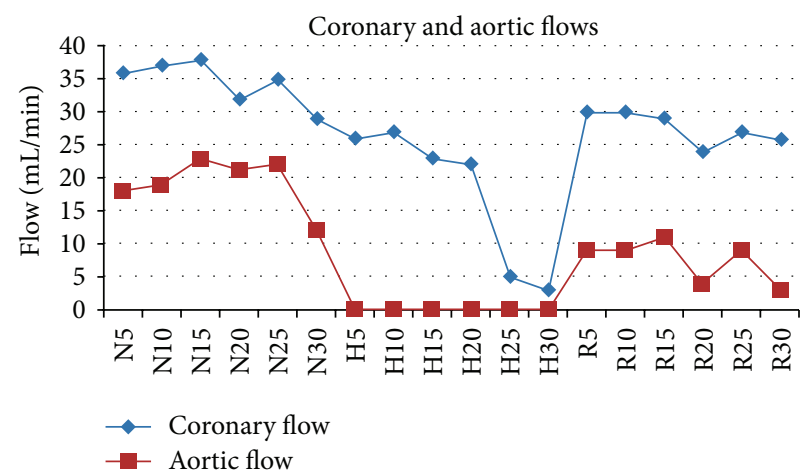

(b)

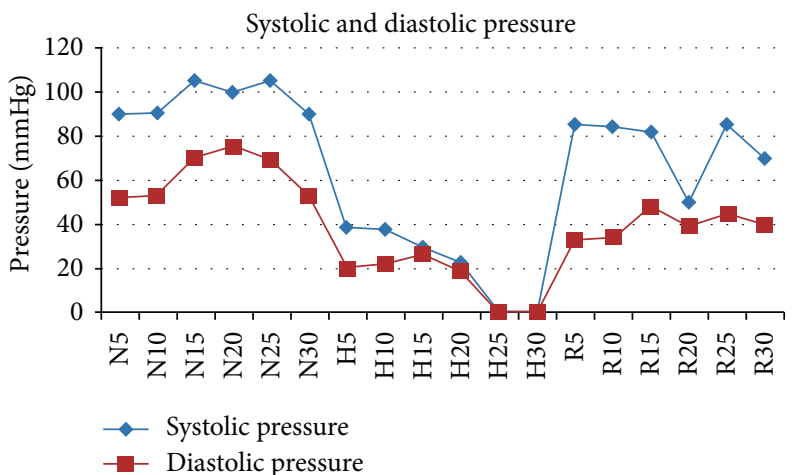

(c)

FIGURE 1: Parameters measured in preliminary experiments: (a) Afterload measured (red squares) during the course of 30 min of normoxia (about $100 \mathrm{~cm}$ water column) immediately dropped within $5 \mathrm{~min}$ of hypoxia to about $35 \mathrm{~cm}$ water column and then slowly decreased to zero between 10 and $25 \mathrm{~min}$ of hypoxia. In reoxygenation, afterload immediately improved again to $60 \mathrm{~cm}$ water column within $5 \mathrm{~min}$ and recovered to around $80 \mathrm{~cm}$ water column between 10 and $30 \mathrm{~min}$ of reoxygenation (red squares). To set up the "working" heart model, afterload was constantly set to $75 \mathrm{~cm}$ water column (blue diamond line). In subsequent experiments, the heart muscle had to pump against this pressure in its cardiac output (systolic phase). (b) Due to our model, aortic flow (red squares) was zero during hypoxia; it was around $20 \mathrm{~mL} / \mathrm{min}$ in normoxia and recovered to about $10 \mathrm{~mL} / \mathrm{min}$ (about $50 \%$ of normoxia) during the first $15 \mathrm{~min}$ of reoxygenation and then started to fluctuate and slowly decreased to almost zero by the end of experimental reoxygenation (R30). Coronary flow (blue diamonds) slowly decreased during normoxia and hypoxia from $35-40 \mathrm{~mL} / \mathrm{min}$ to $3-5 \mathrm{~mL} / \mathrm{min}$ by the end of hypoxia and then recovered rapidly to $30 \mathrm{~mL} / \mathrm{min} \mathrm{in}$ the beginning of reoxygenation and subsequently decreased slightly to $25 \mathrm{~mL} / \mathrm{min}$ within $30 \mathrm{~min}$ of reoxygenation. (c) Systolic pressure (blue diamonds) was $90-100 \mathrm{mmHg}$ in normoxia, dropped to $40 \mathrm{mmHg}$ within $5 \mathrm{~min}$ of hypoxia, and further decreased to zero in $25 \mathrm{~min}$ of hypoxia. Within $5 \mathrm{~min}$ of reoxygenation, systolic pressure immediately recovered to $80-85 \mathrm{mmHg}$ for $15 \mathrm{~min}$ and then started to fluctuate between 50 and $85 \mathrm{mmHg}$ until the end of the experimental reoxygenation (R30). Diastolic pressure (red squares) showed similar course at a lower level with normoxic pressure of $55-75 \mathrm{mmHg}$, decreased to $20-25 \mathrm{mmHg}$ in hypoxia, and dropped to zero after 20-25 min of hypoxia. Recovery during reoxygenation was stable between 35 and $45 \mathrm{mmHg}$ until the end of experimental reoxygenation. These data in preliminary experiments served as the basis of setting up our model in subsequent main experiments with 60 min of hypoxia.

applied. Results are presented as mean values \pm standard deviation (SD); statistical significance is set to $p<0.05$. Furthermore, the means of all normoxic values are set to $100 \%$ and the results of hypoxia, reoxygenation, curcumin $0.25 \mu \mathrm{M}$, and curcumin $0.5 \mu \mathrm{M}$ concentrations expressed as percentage.

2.3. Inclusion-Exclusion Criteria. Our animal housing and experimental procedures strictly followed the Helsinki and Tokyo regulations on animal studies in their actual versions. Guinea pigs were kept in small groups of 3-5 animals with ad libitum access to food and water, in an acclimatized room with a window and thus natural day-and-night light fluctuations. Inclusion criteria for the main experiments were young adult
Guinea pigs, aged one year; body weight 300-400 g; heart rate of the isolated perfused heart between 150 and 250 beats per minute; and coronary flow of the isolated perfused heart during normoxia between 20 and $50 \mathrm{~mL}$.

Exclusion criteria for the main experiments were time between excision of the heart and retrograde perfusion more than $3 \mathrm{~min}$; initial arrhythmias after cannulation longer than $3 \mathrm{~min}$; and afterload = aortic pressure performance: less than $75 \mathrm{~cm}$ water column in normoxia.

2.4. Main Experiments. Conditions in the main experiments are indicated where necessary. Protein was measured according to Lowry et al. [13]; thiobarbituric acid-reactive substances (TBARS) were determined according to Chirico 
[14] using Waters HPLC device with a Spherisorb 5ODS2-C18 column. TBARS are expressed as malondialdehyde (MDA) throughout the text. Glutathione (GSH) was determined with the method of Ellman [15].

Mitochondria were prepared as described by Mela and Seitz [16] omitting nagarse. Relative specific activity of succinate dehydrogenase $(\mathrm{SDH})$ was measured for control: $40 \mu \mathrm{L}$ of the sample was added into a cuvette containing a mixture of $120 \mu \mathrm{L} \mathrm{NaP} 800 \mathrm{mM}, \mathrm{pH} 7.6 ; 120 \mu \mathrm{L}$ $\mathrm{KCN} 10 \mathrm{mM} ; 240 \mu \mathrm{L}$ sodium succinate $100 \mathrm{mM} ; 48 \mu \mathrm{L} 2,6-$ dichlorophenolindophenol $1 \mathrm{mM}$; and $632 \mu \mathrm{L}$ distilled water. The absorption at $\lambda=600 \mathrm{~nm}$ was followed for $5 \mathrm{~min}$ at $37^{\circ} \mathrm{C}$ in a Shimadzu spectrophotometer equipped with a thermostat cuvette holder. We measured relative specific SDH activities between 7.89 and 12.72 to characterize our mitochondrial preparations [17].

Enzyme activity of glutathione peroxidase (GPx) and glutathione reductase (GR) were measured as described by Flohé and Günzler [18] with slight modifications: our reaction mixture contained $200 \mu \mathrm{L}$ GSH $20 \mathrm{mM} ; 200 \mu \mathrm{L}$ sodium azide $20 \mathrm{mM} ; 200 \mu \mathrm{L}$ EDTA $20 \mathrm{mM} ; 200 \mu \mathrm{L}$ NADPH $1 \mathrm{mM}$; and $100 \mu \mathrm{L} \mathrm{NaP}_{i} 0.1 \mathrm{M}, \mathrm{pH}$ 7.0. For measurement of GPx activity, $20 \mu \mathrm{L}$ glutathione reductase $1 \mathrm{U}$ was added and incubated with $60 \mu \mathrm{L}$ isolation buffer at $37^{\circ} \mathrm{C}$ for $10 \mathrm{~min}$. Subsequently, $20 \mu \mathrm{L}$ of mitochondrial preparation was added and absorption followed for $5 \mathrm{~min}$ at $\lambda=340 \mathrm{~nm}$. For measurement of glutathione reductase, instead of $20 \mu \mathrm{L}$ glutathione reductase $1 \mathrm{U}$, glutathione peroxidase was added, accordingly. All photometric measurements were accomplished in a Shimadzu spectrophotometer equipped with a thermostat cuvette holder.

\section{Results}

3.1. Preliminary Experiments. The time course of our model with normoxia, hypoxia, and reoxygenation, $30 \mathrm{~min}$ each, is depicted in Figure 1. In our preliminary experiments, hypoxia varied, 15, 30, or $60 \mathrm{~min}$; throughout the main experiments hypoxia was set to $60 \mathrm{~min}$.

Heart rate was between 173 and 217 beats per minute and turned out to be a stable parameter in our experimental setting: it recovered after 15 and $30 \mathrm{~min}$ of hypoxia in reoxygenation to $100.5 \%$ and $98.9 \%$, respectively, without curcumin, and to $97.1 \%$ and $101.7 \%$, respectively, with 0.25 and $0.5 \mu \mathrm{M}$ curcumin. Differences between all these values were statistically not significant indicating that the hearts were stable over the experimental course of our model.

For measurement of systolic pressure a water column in our device $[7,11]$ with normoxic values up to $100 \mathrm{~cm}$ was used corresponding to and exceeding the constant afterload water column of $75 \mathrm{~cm}$, against which the isolated heart had to perform its work. In addition, systolic and diastolic pressure were measured using a mercury manometer (Figure 1(c)).

3.1.1. Histopathology and Aspartate Aminotransferase (AST). Histopathological changes depended on the duration of hypoxia: in hypoxia up to $15 \mathrm{~min}$ we did not observe changes in tissue ultrastructure; however, changes became visible at $30 \mathrm{~min}$ and, particularly after $60 \mathrm{~min}$, destruction of the myocardium was obvious (not shown). This result mirrored the measurement of AST activity in the perfusate: with only after 60 min of hypoxia, AST activity increased significantly during reoxygenation indicating tissue damage and release of AST from cardiomyocytes into the perfusate.

3.2. Main Experiments. For the main experiments, the following experimental settings were chosen: normoxia $30 \mathrm{~min}$, hypoxia $60 \mathrm{~min}$, and subsequent reoxygenation $30 \mathrm{~min}$. Curcumin was injected into the perfusion buffer at $0.25 \mu \mathrm{M}$ or $0.5 \mu \mathrm{M}$ concentrations after $15 \mathrm{~min}$ of normoxic perfusion.

3.2.1. Cardiac Parameters. Cardiac parameters measured were systolic pressure, aortic flow, and coronary flow (Table 1).

3.2.2. Myocardial Tissue. Myocardial tissue parameters measured are shown in Table 2.

(1) Aspartate Aminotransferase (AST). After $60 \mathrm{~min}$ of hypoxia, AST activity increased significantly during reoxygenation indicating tissue damage and release of AST from cardiomyocytes into the perfusate (Table 2). Curcumin, at $0.25 \mu \mathrm{M}$ concentration, protected the myocardium from AST release significantly from $139.9 \%$ in reoxygenation to normoxic values. This protective effect was significant with $0.25 \mu \mathrm{M}(p<0.05)$ but not with $0.5 \mu \mathrm{M}$ concentration (Table 2).

(2) Thiobarbituric Acid-Reactive Substances (TBARS)/Malondialdehyde (MDA). Lipid peroxidation (LPO) is considered a major reason of membrane destruction; LPO is often determined via thiobarbiturate reaction and expressed through its byproduct malondialdehyde (MDA). As can be seen in Table 2, MDA increased to $232.5 \%$ of normoxia (8.33 \pm $5.30 \mathrm{nmol} \times \mathrm{g}^{-1}$ tissue, $\left.100 \%\right)$ during reoxygenation $(19.37 \pm$ $8.31 \mathrm{nmol} \times \mathrm{g}^{-1}$ tissue) after $60 \mathrm{~min}$ of hypoxia. Although during hypoxia $0.5 \mu \mathrm{M}$ concentration of curcumin had a stronger effect than $0.25 \mu \mathrm{M}$, both concentrations equally reduced MDA levels to $150 \%$ in reoxygenation.

3.2.3. Mitochondrial Parameters. The mitochondrial parameters measured are presented in Table 3.

(1) Thiobarbituric Acid-Reactive Substances (TBARS). Mitochondrial TBARS levels are expressed as nmol MDA per $\mathrm{g}$ mitochondrial protein $(n=6)$. We found higher levels in normoxic mitochondria than in myocardial tissue if correlated to mitochondrial protein, $17.85 \pm 2.79$ (100\%). During hypoxia the increase to $119 \%$ was only moderate but significant in reoxygenation, $165.4 \%(p<0.05$ versus $\mathrm{N})$. Curcumin diminished mitochondrial MDA levels to normoxia at $0.25 \mu \mathrm{M}$ concentration ( $\mathrm{R}$ versus $\mathrm{R}_{0.25} ; p<0.05$ ), whereas $0.5 \mu \mathrm{M}$ concentration of curcumin was less effective (Table 3).

(2) Reduced Glutathione (GSH). Mitochondrial GSH decreased from $40.6 \pm 10.9 \mathrm{nmol} \times \mathrm{mg}^{-1}$ protein in normoxia $(100 \%)$ to $56.4 \%$ in hypoxia $(p=0.011$ versus $N$ ) and $35.2 \%$ in reoxygenation $(p<0.001$ versus $N)$. During hypoxia, 
TABLE 1: Cardiac parameters.

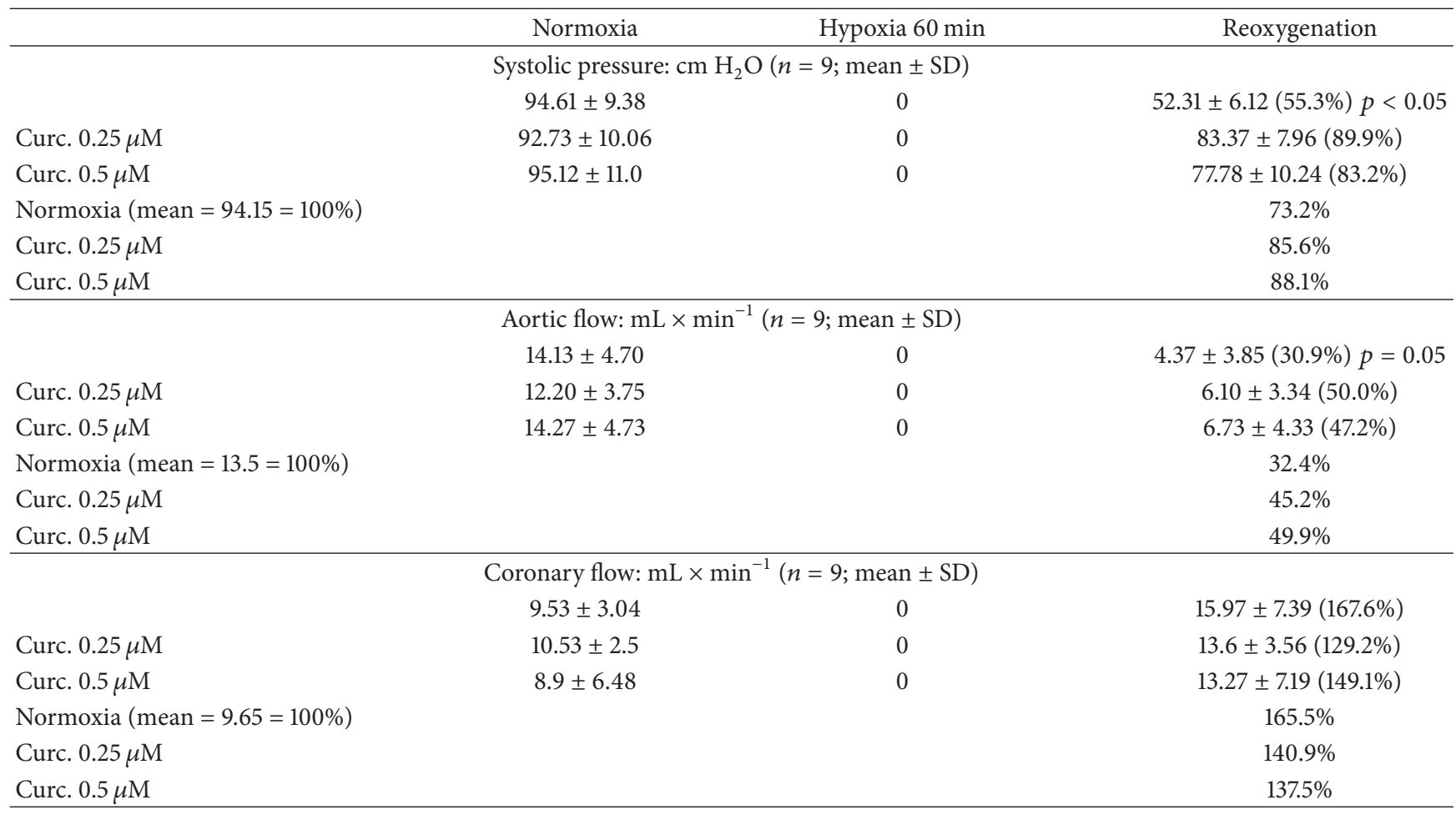

TABLE 2: Myocardial tissue parameters.

\begin{tabular}{|c|c|c|c|}
\hline & Normoxia & Hypoxia & Reoxygenation \\
\hline \multicolumn{4}{|c|}{ Aspartate aminotransferase (AST) } \\
\hline \multicolumn{4}{|c|}{ AST: $\mathrm{U} \times \mathrm{L}^{-1} \times \mathrm{g}^{-1}$ heart tissue $(n=5$; mean $\pm \mathrm{SD})$} \\
\hline & $2934+1451(100 \%)$ & $3249+1119(1107 \%)$ & $4.105 \pm 1.917(139.9 \%)$ \\
\hline & $2.934 \pm 1.451(100 \%)$ & $3.249 \pm 1.119(110.1 \%)$ & $\mathrm{N}$ versus $\mathrm{R} p=0.05$ \\
\hline \multirow{2}{*}{ Curc. $0.25 \mu \mathrm{M}$} & & \multirow{2}{*}{$3.382 \pm 2.149(115.3 \%)$} & $2.397 \pm 0.901(81.7 \%)$ \\
\hline & & & $\mathrm{R}$ versus $\mathrm{R}_{0.25} p<0.05$ \\
\hline Curc. $0.5 \mu \mathrm{M}$ & & $3.671 \pm 1.446(125.1 \%)$ & $3.192 \pm 1.516(108.8 \%)$ \\
\hline
\end{tabular}

TBARS, expressed as malondialdehyde (MDA)

MDA: $n m o l \times \mathrm{g}^{-1}$ heart tissue $\left(n=6\right.$; mean $\pm \mathrm{SD}$; $\mathrm{N}$ versus $\mathrm{R}$ and $\mathrm{H}$ versus $\left.\mathrm{H}_{0.5} p<0.05\right)$

$$
\begin{array}{ccc}
8.33 \pm 5.30(100 \%) & 9.36 \pm 6.24(112.4 \%) & 19.37 \pm 8.31(232.5 \% ; \mathrm{N} \text { versus } \mathrm{R} p<0.05) \\
& 8.86 \pm 0.48(106.4 \%) & 12.46 \pm 10.30(149.6 \%) \\
& 5.88 \pm 5.85(70.6 \%) & 12.52 \pm 6.85(150.3 \%) \\
& {\text { H versus } \mathrm{H}_{0.5}(p<0.05)}
\end{array}
$$

Curc. $0.25 \mu \mathrm{M}$

The activity of AST was measured in the perfusate as $\mathrm{U} \times \mathrm{L}^{-1}$ and then correlated to the weight of the heart (= g heart tissue). TBARS, thiobarbituric acid reactive substances; $\mathrm{N}$, normoxia; $\mathrm{H}$, hypoxia; $\mathrm{R}$, reoxygenation; $\mathrm{R}_{0.25}$, reoxygenation with curcumin (curc.) $0.25 \mu \mathrm{M} ; \mathrm{H}_{0.5}$, hypoxia with $0.5 \mu \mathrm{M}$ curc.

curcumin did not have much effect, but in reoxygenation it significantly increased GSH at both concentrations (Table 3).

(3) Glutathione Peroxidase (GPx). Glutathione peroxidase activity was $324.1 \pm 115.0 \mathrm{nmol} \times \mathrm{min}^{-1} \times \mathrm{mg}^{-1}$ protein in normoxia (100\%). During hypoxia GPx activity increased slightly to $121.1 \%$ and in reoxygenation significantly to $255.2 \%$. Curcumin, at $0.25 \mu \mathrm{M}$ concentration, attenuated GPx activity to about $150 \%$ and at $0.5 \mu \mathrm{M}$ concentration to about $200 \%$, both during hypoxia and reoxygenation (Table 3 ).
(4) Glutathione Reductase (GR). Glutathione reductase activity was $77.2 \pm 15.7 \mathrm{nmol} \times \mathrm{min}^{-1} \times \mathrm{mg}^{-1}$ protein in normoxia (100\%). During hypoxia GR activity decreased moderately to $58.8 \%$ and in reoxygenation significantly to $29.3 \%$ ( $p<$ 0.05). During hypoxia, curcumin did not have a significant effect on GR activity, but, in reoxygenation, $0.25 \mu \mathrm{M}$ concentration increased GR activity to $46.8 \%$ and $0.5 \mu \mathrm{M}$ concentration significantly increased GR activity to $62.0 \%$ (R versus $\left.\mathrm{R}_{0.5} p=0.006\right)$. Interestingly, values with curcumin were almost the same during hypoxia and reoxygenation, 
TABLE 3: Mitochondrial parameters.

\begin{tabular}{|c|c|c|c|}
\hline & Normoxia & Hypoxia & Reoxygenation \\
\hline \multicolumn{4}{|c|}{ MDA: $\mathrm{nmol} \times \mathrm{mg}^{-1}$ mitochondrial protein $\left(n=6\right.$; mean $\pm \mathrm{SD} ; \mathrm{N}$ versus $\mathrm{R}$ and $\mathrm{R}$ versus $\left.\mathrm{R}_{0.25} p<0.05\right)$} \\
\hline & \multirow[t]{3}{*}{$17.85 \pm 2.79(100 \%)$} & $21.24 \pm 3.53(119.0 \%)$ & $29.52 \pm 9.47(165.4 \% ; \mathrm{N}$ versus $\mathrm{R} ; p<0.05)$ \\
\hline Curc. $0.25 \mu \mathrm{M}$ & & $17.68 \pm 4.40(99.1 \%)$ & $16.47 \pm 1.99\left(92.3 \% ; \mathrm{R}\right.$ versus $\left.\mathrm{R}_{0.25} ; p<0.05\right)$ \\
\hline Curc. $0.5 \mu \mathrm{M}$ & & $19.93 \pm 3.62(111.7 \%)$ & $24.45 \pm 3.24(137.0 \%)$ \\
\hline \multicolumn{4}{|c|}{ GSH: $\mathrm{nmol} \times \mathrm{mg}^{-1}$ protein $(n=6$ in each group; mean $\pm \mathrm{SD})$} \\
\hline \multirow{4}{*}{ Curc. $0.25 \mu \mathrm{M}$} & \multirow{6}{*}{$40.6 \pm 10.9(100 \%)$} & $22.9 \pm 10.7(56.4 \%)$ & $14.3 \pm 4.3(35.2 \%)$ \\
\hline & & $\mathrm{N}$ versus $\mathrm{H}(p=0.011)$ & $\mathrm{N}$ versus $\mathrm{R}(p<0.001)$ \\
\hline & & $19.5 \pm 7.1(48.0 \%)$ & \multirow{2}{*}{$\begin{array}{c}27.0 \pm 11.2(66.5 \%) \\
\text { R versus } \mathrm{R}_{0.25}(p<0.05)\end{array}$} \\
\hline & & \multirow{3}{*}{$23.2 \pm 7.0(57.1 \%)$} & \\
\hline \multirow{2}{*}{ Curc. $0.5 \mu \mathrm{M}$} & & & $28.3 \pm 8.0(69.7 \%)$ \\
\hline & & & $\mathrm{R}$ versus $\mathrm{R}_{0.5}(p<0.05)$ \\
\hline \multicolumn{4}{|c|}{ GPx: $\mathrm{nmol} \times \mathrm{min}^{-1} \times \mathrm{mg}^{-1}$ protein $(n=6$ in each group; mean $\pm \mathrm{SD})$} \\
\hline & \multirow{4}{*}{$324.1 \pm 115.0(100 \%)$} & $392.2 \pm 150.1(121.1 \%)$ & $826.1 \pm 268.0(255.2 \%)$ \\
\hline & & H versus $\mathrm{R}(p<0.05)$ & $\mathrm{N}$ versus $\mathrm{R}(p<0.05)$ \\
\hline \multirow{2}{*}{ Curc. $0.25 \mu \mathrm{M}$} & & \multirow{2}{*}{$513.3 \pm 59.4(158.6 \%)$} & $498.6 \pm 44.5(153.8 \%)$ \\
\hline & & & $\mathrm{R}$ versus $\mathrm{R}_{0.25}(p<0.05)$ \\
\hline Curc. $0.5 \mu \mathrm{M}$ & & $664.4 \pm 206.3(205.3 \%)$ & $665.0 \pm 219.1(205.7 \%)$ \\
\hline \multicolumn{4}{|c|}{ GR: $\mathrm{nmol} \times \mathrm{min}^{-1} \times \mathrm{mg}^{-1}$ protein $(n=6$ in each group; mean $\pm \mathrm{SD})$} \\
\hline & $77.2 \pm 15.7(100 \%)$ & $45.3 \pm 17.1(58.8 \%)$ & $22.2 \pm 9.6(29.3 \% ; \mathrm{N}$ versus $\mathrm{R} p<0.05)$ \\
\hline Curc. $0.25 \mu \mathrm{M}$ & & $36.9 \pm 16.9(48.8 \%)$ & $35.4 \pm 16.0(46.8 \%)$ \\
\hline Curc. $0.5 \mu \mathrm{M}$ & & $47.3 \pm 18.6(62.5 \%)$ & $46.9 \pm 18.5\left(62.0 \% ; \mathrm{R}\right.$ versus $\left.\mathrm{R}_{0.5} p=0.006\right)$ \\
\hline
\end{tabular}

$48.8 \%$ and $46.8 \%$ at $0.25 \mu \mathrm{M}$ concentration, $62.5 \%$ and $62.0 \%$ at $0.5 \mu \mathrm{M}$ concentration (Table 3 ).

\section{Discussion}

In our experiments Guinea pig hearts were more stable than rat hearts over the experimental time course of one hour and thus more suitable to our experimental conditions in Jakarta. The discussion about the stability of the performance of isolated perfused hearts goes back almost four decades; isolated perfused Guinea pig hearts had been considered more stable than rat hearts by some working groups, whereas others could not confirm any differences, which may strongly depend on the experimental conditions [19-26]. We do not want to go into the discussion about differences in metabolic pathways (e.g., endogenous synthesis of ascorbic acid) and whether environmental (e.g., tropical) conditions may play a role. However, we state from our own experience that the slightly bigger Guinea pig hearts make it easier to fix them to the cannulas of the apparatus and thus reduce initial complications such as arrhythmias.

4.1. Main Experiments: Cardiac Parameters. In the main experiments hypoxia was set to $60 \mathrm{~min}$ and systolic pressure, aortic flow, and coronary flow were measured as cardiac parameters. Two concentrations of curcumin in the reoxygenation buffer were applied, $0.25 \mu \mathrm{M}$ and $0.5 \mu \mathrm{M}$, but, generally, $0.5 \mu \mathrm{M}$ curcumin did not exert higher effects than $0.25 \mu \mathrm{M}$ concentration (after we had already ruled out $1 \mathrm{mM}$ concentration of curcumin in our preliminary experiments).

Systolic pressure recovered during reoxygenation by $55-$ $56 \%$, under $0.25 \mu \mathrm{M}$ curcumin between $85 \%$ and $90 \%$ and under $0.5 \mu \mathrm{M}$ curcumin between $83 \%$ and $88 \%$. Aortic flow recovered to $31-32 \%$ during reoxygenation, under $0.25 \mu \mathrm{M}$ curcumin between $45 \%$ and $50 \%$ and under $0.5 \mu \mathrm{M}$ curcumin between $47 \%$ and $50 \%$.

Coronary flow exerted an overshooting reaction of almost $170 \%$ during reoxygenation. This overshoot might depend on the experimental setting of the isolated heart. Coronary flow was measured as the amount of buffer dropping down from the heart's perfused coronary arteries and sinus coronarius. Hence, the "coronary flow" especially during reoxygenation might be a mixture of coronary perfusion and leakiness of coronary vessels. The increase of about $70 \%$ over the normoxic value was certainly due to the leakiness of the coronary blood vessels after 60 minutes of hypoxia.

Leakiness of blood vessels is a well-known and dreadful reoxygenation/reperfusion phenomenon often causing considerable edema in tissues as part of ischemia-reperfusion injury [1-3]. Hence, the influence of curcumin in lowering 
this overshoot can be considered a positive therapeutic effect. Curcumin, at $0.25 \mu \mathrm{M}$ concentration, reduced the overshoot to roughly $140 \%$ and at $0.5 \mu \mathrm{M}$ concentration to about $138 \%$. Thus, coronary flow under the aspect of ischemia-reperfusion injury did not improve much better with $0.5 \mu \mathrm{M}$ than with $0.25 \mu \mathrm{M}$ concentration of curcumin.

4.2. Myocardial Tissue. After $60 \mathrm{~min}$ of hypoxia lipid peroxidation destroyed cell membranes and cardiomyocytes became leaky and released AST into the perfusate, where its enzymatic activity increased during reoxygenation; in parallel, also MDA increased to about 233\%. During reoxygenation curcumin reduced AST activity significantly at $0.25 \mu \mathrm{M}(p<0.05)$, but not at $0.5 \mu \mathrm{M}$ concentration $(p>$ $0.05)$. Curcumin reduced MDA significantly during hypoxia only at $0.5 \mu \mathrm{M}$, but not at $0.25 \mu \mathrm{M}$ concentration, whereas both concentrations reduced equally MDA tissue levels from $233 \%$ in reoxygenation to about $150 \%$.

Thiobarbiturate is the mostly used reagent to measure lipid peroxidation (LPO) and the result is expressed as TBARS (thiobarbituric acid-reactive substances) or as one of the major byproducts of LPO, MDA. These parameters are widely used as markers of oxidative stress and tissue damage. Recently, discussions have been extended about the concept of oxidative damage and the value of LPO and MDA as generalized markers of oxidative stress in cells, tissues, and body fluids. We do not go into this discussion here; however, one point of criticism often raised is that the markers are not determined at the place of origin. Hence, we tried to overcome this point by differentiating MDA as a parameter of tissue damage, measured from myocardium, and MDA measured from mitochondria as a parameter of LPO in mitochondrial membranes.

In general, $0.5 \mu \mathrm{M}$ curcumin did not exert higher effects on myocardial tissue parameters (AST, MDA) than $0.25 \mu \mathrm{M}$ concentration.

4.3. Mitochondrial Parameters. Mitochondrial MDA level was only decreased significantly during reoxygenation by $0.25 \mu \mathrm{M}$ curcumin, but not by $0.5 \mu \mathrm{M}$ concentration. At both concentrations, curcumin increased significantly mitochondrial GSH content during reoxygenation, whereas, during hypoxia, no significant effects on MDA and glutathione were observed. We were interested in the activities of glutathione reductase and glutathione peroxidase under the same conditions: The activity of glutathione reductase mirrored well the content of reduced glutathione. During reoxygenation curcumin exerted a significantly stimulating effect on GR at $0.5 \mu \mathrm{M}$, but not at $0.25 \mu \mathrm{M}$ concentration. At either concentration, GR activity was almost the same during hypoxia and reoxygenation.

Glutathione peroxidase was slightly increased in hypoxia, but during reoxygenation its activity was tremendously high, $255 \%$ of normoxic control values. Curcumin, at $0.25 \mu \mathrm{M}$ concentration, attenuated GPx to about 154\% ( $p<0.05)$ and at $0.5 \mu \mathrm{M}$ to $206 \%$ ( $p>0.05)$. Interestingly, at both concentrations, GPx had the same activity in hypoxia and reoxygenation of about $150 \%(0.25 \mu \mathrm{M}$ curcumin $)$ and $200 \%$ $(0.5 \mu \mathrm{M}$ curcumin $)$ of normoxic values. Hence, curcumin, in two concentrations used in our experiments, appeared to be an independent attenuator of both GR and GPx during hypoxia and reoxygenation. Interestingly, on GR $0.5 \mu \mathrm{M}$ curcumin had a stronger effect than $0.25 \mu \mathrm{M}$ concentration, whereas the overshoot of GPx activity in reoxygenation was downregulated more strongly by 0.25 than by $0.5 \mu \mathrm{M}$ of curcumin.

Protective effects through enhanced GPx during hypoxia and reoxygenation in other organs have been reported [27-29]; in human plasma GPx-3 isoenzyme was threefold increased over normal expression during hypoxia [30]. On the contrary, Manikandan et al. [31] reported decreased GPx activity during isoprenaline induced myocardial ischemia in rats. Curcumin at $15 \mathrm{mg} \times \mathrm{kg}^{-1}$ body weight (pre- and postischemic application) managed to normalize GPx activity, whereas curcumin administered either pre- or postischemically had much lower effects.

Animal and organ distribution of cGPx was reported to be low in Guinea pig hearts [32] and less than onethird of the activity found in isolated mouse heart atria was detected in Guinea pigs [33]. On the other hand, overexpression of PHGPx protected a guinea pig cell line from LPO-mediated injury [34]. In mitochondria, two isoforms out of various GPx isoenzymes [35, 36] appear to exist, for example, cGPx (GPx-1) and PHGPx (GPx-4) [37, 38], and $\mathrm{GPx}-1$ was reported to protect mouse heart mitochondria against hypoxia/reoxygenation injury [28]. Transgenic mice overexpressing cGPx were protected against cerebral ischemia/reperfusion injury and apoptosis induced by it, whereas cGPX-mutant mice and nontransgenic control animals were more susceptible [39]. In this context, selenium dependence of GPx isoenzymes should be considered, which differs "hierarchically" between isoforms [32] and we suggest that it should be the scope of future studies with our isolated perfused working guinea pig heart model [40].

During reoxygenation GPx was considerably increased to $255 \%$ of control values. Increased GPx activity consumes more GSH and produces GSSG; GR activity is needed to replenish reduced GSH, but diminished GR activity will lead to GSH depletion in hypoxia and reoxygenation. Attenuation of GPx activity by curcumin and concomitant slight stimulation of GR activity, as observed in our model, would help to prevent rapid GSH depletion.

At higher concentration up to $2.5 \mu \mathrm{M}$ curcumin was reported to protect rat liver mitochondria against tert-butylhydroxyperoxide- ( $t$-BHP-) induced mitochondrial dysfunction, such as breakdown of transmembrane potential and swelling $[17,41]$. On the other hand, at these concentrations curcumin was suspected to consume reduced glutathione [41]. It was assumed that curcumin participates in phenoxylradical recycling mechanisms as demonstrated for tocopherol and other phenolic compounds [42-44]. Such reductive "recycling" mechanisms involve reduced GSH $[43,44]$ and may consume glutathione at higher concentrations of curcumin (and other phenolic antioxidants) and thus contribute to GSH depletion during oxidative stress [17, 45]. Although these mechanisms still need further clarification, they may be the reason for prooxidant effects at higher concentrations; we had to rule out $1 \mu \mathrm{M}$ curcumin in our preliminary 
experimentation and did not see a clear advantage of $0.5 \mu \mathrm{M}$ over $0.25 \mu \mathrm{M}$ concentration in some results of our main experiments.

In literature, curcumin concentrations differ considerably between experimental settings. Hence, it is difficult to compare results, especially since pharmacokinetic data are often missing. Pan et al. [46] investigated pharmacokinetic parameters of curcumin in mice: one $\mathrm{mg} \times \mathrm{kg}^{-1}$ body weight peaked in $0.5 \mu \mathrm{M}$ plasma concentration, $50 \%$ of which was metabolized within $8 \mathrm{~h}$. The concentrations in our perfusion buffer correlated to these data. In a Langendorff rat heart model [8] GPx was not much influenced by curcumin, whereas GR was stimulated. The differences with our results on GPx activity may be due to different animals and the experimental model. In the Langedorff preparation the isolated heart is perfused retrogradely, whereas in our model the isolated working heart is perfused anterogradely and its mechanical work is closer to physiological conditions. Their study, which only presented one value for ischemia-reperfusion (I/R) observed a decrease in GR activity during I/R to almost $47 \%$ [8]. Their value is very close to the average (about $44 \%$ ) of our values in hypoxia (58.8\%) and reoxygenation $(29.3 \%)$. This decrease of GR during I/R can only be considered as an enzymatic or metabolic dysregulation, because the low GR activity cannot replenish higher GSH consumption by the oxidative stress during hypoxia/ischemia-reoxygenation/reperfusion, including the overshoot of GPx. Metabolic dysregulations (e.g., calcium paradox) have been observed in the scenario of ischemia-reperfusion injury [1-3].

Curcumin appeared to be an independent regulator of GR and GPx activities under our experimental conditions. In hypoxia and in reoxygenation, $0.25 \mu \mathrm{M}$ concentration of curcumin attenuated GPx activity to $150 \%$ and $0.5 \mu \mathrm{M}$ concentration of curcumin attenuated GPx to $200 \%$ of normoxic activity and, thus, moderately reduced the overshoot of GPx activity during reoxygenation. Concomitantly, curcumin attenuated GR during reoxygenation through moderate upregulation with $0.25 \mu \mathrm{M}$ curcumin and significant upregulation with $0.5 \mu \mathrm{M}$ concentration; in other words, towards GR $0.5 \mu \mathrm{M}$ curcumin was more effective than the lower concentration. This attenuating effect on GR activity by curcumin was also observed in the Langendorff preparation by the before-mentioned study [8].

These considerations demonstrate that the concentration of curcumin is crucial to its metabolic effects; that is, the dosage of curcumin determines whether it exerts therapeutic activity. Moreover, the therapeutic efficacy of curcumin appears to go beyond its antioxidant effects [47, 48]: curcumin exerts regulatory effects on expression and activity of the enzymes involved in mitochondrial glutathione turnover.

\section{Conclusion}

In our experimental setting of the isolated perfused working Guinea pig heart curcumin exerts protection against hypoxiareoxygenation injury at $0.25 \mu \mathrm{M}$ and $0.5 \mu \mathrm{M}$ concentrations on cardiac parameters and myocardial tissue damage and on mitochondrial GSH turnover. The higher concentration did not exert advantages over the lower one on cardiac parameters and myocardial tissue. On parameters of mitochondrial GSH turnover measured in our study, $0.5 \mu \mathrm{M}$ concentration was only advantageous towards GR. In clinical cardio protective dose determination it should be considered that curcumin appears to have an upper dose limitation towards cardiac ischemia-reperfusion injury.

\section{Conflict of Interests}

The authors declare that there is no conflict of interests regarding the publication of this paper.

\section{Acknowledgments}

The authors are especially thankful to Professor Zimmer, posthumously, who had donated the entire perfusion device to the Medical Faculty at Universitas Indonesia. His Guest Professorship in Jakarta, in 1998, was supported by the German Academic Exchange Service (DAAD). Financial support to this research project by the URGE Program of the Indonesian Government and assistance by the DeutschIndonesische Gesellschaft für Medizin (DIGM e.V.) as well as the Indonesian Society For Free Radical Research (INASFRR) are also gratefully acknowledged. Furthermore, the authors want to express their gratitude to Dr. Gordon $\mathrm{McD}$ onald for proofreading the paper.

\section{References}

[1] H.-J. Freisieben, "Lipoate ameliorates ischemia-reperfusion in animal models," Clinical Hemorheology and Microcirculation, vol. 23, no. 2-4, pp. 219-224, 2000.

[2] A. Hanselmann, F. Beyersdorf, G. Matheis et al., "Verminderung des Postischämie-Syndroms nach akutem peripherem Gefäßverschluß durch Modifikation der initialen Reperfusion unter Berücksichtigung des Kalziumgehaltes des Reperfusates," Zeitschrift für Herz-, Thorax- und Gefäßchirurgie, vol. 4, pp. 1320, 1990 (German).

[3] Z. Mitrev, F. Beyersdorf, R. Hallmann et al., "Reperfusion in skeletal muscle: controlled limb reperfusion reduces local and systemic complications after prolonged ischemia," Cardiovascular Surgery, vol. 2, no. 6, pp. 737-748, 1994.

[4] K. Ytrehus, "The ischemic heart-experimental models," Pharmacological Research, vol. 42, no. 3, pp. 193-203, 2000.

[5] J. R. Neely, H. Liebermeister, E. J. Battersby, and H. E. Morgan, "Effect of pressure development on oxygen consumption by isolated rat heart," American Journal of Physiology, vol. 212, no. 4, pp. 804-814, 1967.

[6] O. Langendorff, "Untersuchungen am überlebenden Säugetierherzen," Pflüger, Archiv für die Gesammte Physiologie des Menschen und der Thiere, vol. 61, no. 6, pp. 291-332, 1895.

[7] H.-J. Freisleben, H. Kriege, C. Clarke, F. Beyersdorf, and G. Zimmer, "Hemodynamic and mitochondrial parameters during hypoxia and reoxygenation in working rat hearts," ArzneimittelForschung/Drug Research, vol. 41, no. 1, pp. 81-88, 1991.

[8] A. González-Salazar, E. Molina-Jijón, F. Correa et al., "Curcumin protects from cardiac reperfusion damage by attenuation of oxidant stress and mitochondrial dysfunction," Cardiovascular Toxicology, vol. 11, no. 4, pp. 357-364, 2011. 
[9] W. Wongcharoen and A. Phrommintikul, "The protective role of curcumin in cardiovascular diseases," International Journal of Cardiology, vol. 133, no. 2, pp. 145-151, 2009.

[10] A. Goel, A. B. Kunnumakkara, and B. B. Aggarwal, "Curcumin as 'Curecumin': from kitchen to clinic," Biochemical Pharmacology, vol. 75, no. 4, pp. 787-809, 2008.

[11] B. Deisinger and H.-J. Freisleben, "Animal models in hypoxia/reoxygenation and ischemia/reperfusion: II. Perfusion procedures," The Indonesian Journal of Vascular Surgery, vol. 2, no. 1, pp. 1-12, 1998.

[12] H. A. Krebs and K. Henseleit, "Untersuchungen über die Harnstoffbildung im Tierkörper," Biological Chemistry HoppeSeyler, vol. 210, pp. 33-66, 1932 (German).

[13] O. H. Lowry, N. J. Rosenbrough, A. L. Farr, and R. J. Randall, "Protein measurement with the Folin phenol reagent," The Journal of Biological Chemistry, vol. 193, no. 1, pp. 265-275, 1951.

[14] S. Chirico, "High-performance liquid chromatography-based thiobarbituric acid tests," Methods in Enzymology, vol. 234, pp. 314-318, 1994.

[15] G. L. Ellman, "Tissue sulfhydryl groups," Archives of Biochemistry and Biophysics, vol. 82, no. 1, pp. 70-77, 1959.

[16] L. Mela and S. Seitz, "Isolation of mitochondria with emphasis on heart mitochondria from small amount of tissue," Methods in Enzymology, vol. 55, pp. 39-46, 1979.

[17] S. Susilowati, F. D. Suyatna, and A. Setiawati, "The prevention of curcumin against rat liver mitochondrial swelling induced by tert-butylhydroperoxide," Medical Journal of Indonesia, vol. 15, no. 3, pp. 131-136, 2006.

[18] L. Flohé and W. A. Günzler, "Assays of glutathione peroxidase," Methods in Enzymology, vol. 105, pp. 114-121, 1984.

[19] R. Bünger, F. J. Haddy, A. Querengässer, and E. Gerlach, "An isolated guinea pig heart preparation with in vivo like features," Pflügers Archiv-European Journal of Physiology, vol. 353, no. 4, pp. 317-326, 1975.

[20] R. Bünger, O. Sommer, G. Walter, H. Stiegler, and E. Gerlach, "Functional and metabolic features of an isolated perfused guinea pig heart performing pressure-volume work," Pflügers Archiv, vol. 380, no. 3, pp. 259-266, 1979.

[21] R. Bünger, B. Swindall, D. Brodie, D. Zdunek, H. Stiegler, and G. Walter, "Pyruvate attenuation of hypoxia damage in isolated working guinea-pig heart," Journal of Molecular and Cellular Cardiology, vol. 18, no. 4, pp. 423-438, 1986.

[22] S. B. Flynn, R. W. Gristwood, and D. A. A. Owen, "Characterization of an isolated, working guinea-pig heart including effects of histamine and noradrenaline," Journal of Pharmacological Methods, vol. 1, no. 3, pp. 183-195, 1978.

[23] B. Gessner, E. R. Müller-Ruchholtz, and H. Reinauer, "Regulation der pyruvatdehydrogenaseaktivität und dynamik des isoliert perfundierten meerschweinchenherzens im thiaminmangel," Pflügers Archiv, vol. 334, no. 4, pp. 327-344, 1972.

[24] H. L. Maddock, K. J. Broadley, A. Bril, and N. Khandoudi, "Effects of adenosine receptor agonists on guinea-pig isolated working hearts and the role of endothelium and NO," Journal of Pharmacy and Pharmacology, vol. 54, no. 6, pp. 859-867, 2002.

[25] S. Soboll, R. Buenger, M. Müller, and O. Sommer, "Compartmentation of adenine nucleotides in the isolated working guinea pig heart stimulated by noradrenaline," Biological Chemistry Hoppe-Seyler, vol. 362, no. 2, pp. 125-132, 1981.

[26] R. R. Suwito, Die langzeitstabilität isolierter, unterschiedlich belasteter, arbeitender rattenherzen bei zusatz von pyruvat zum perfusionsmedium [Dissertation], Freie Universität Berlin, Berlin, Germany, 1983 (German).
[27] D. A. Lepore, T. A. Shinkel, N. Fisicaro et al., "Enhanced expression of glutathione peroxidase protects islet $\beta$ cells from hypoxia-reoxygenation," Xenotransplantation, vol. 11, no. 1, pp. 53-59, 2004.

[28] V. T. Thu, H. K. Kim, S. H. Ha et al., "Glutathione peroxidase 1 protects mitochondria against hypoxia/reoxygenation damage in mouse hearts," Pflügers Archiv, vol. 460, no. 1, pp. 55-68, 2010.

[29] C. W. White, J. H. Jackson, I. F. McMurtry, and J. E. Repine, "Hypoxia increases glutathione redox cycle and protects rat lungs against oxidants," Journal of Applied Physiology, vol. 65, no. 6, pp. 2607-2616, 1988.

[30] C. Bierl, B. Voetsch, R. C. Jin, D. E. Handy, and J. Loscalzo, "Determinants of human plasma glutathione peroxidase (GPx3) expression," The Journal of Biological Chemistry, vol. 279, no. 26, pp. 26839-26845, 2004.

[31] P. Manikandan, M. Sumitra, S. Aishwarya, B. M. Manohar, B. Lokanadam, and R. Puvanakrishnan, "Curcumin modulates free radical quenching in myocardial ischaemia in rats," The International Journal of Biochemistry \& Cell Biology, vol. 36, no. 10, pp. 1967-1980, 2004.

[32] R. Brigelius-Flohé, "Tissue-specific functions of individual glutathione peroxidases," Free Radical Biology and Medicine, vol. 27, no. 9-10, pp. 951-965, 1999.

[33] M. Floreani, E. Napoli, and P. Palatini, "Role of antioxidant defences in the species-specific response of isolated atria to menadione," Comparative Biochemistry and Physiology Part C: Toxicology \& Pharmacology, vol. 132, no. 2, pp. 143-151, 2002.

[34] K. Yagi, S. Komura, H. Kojima et al., "Expression of human phospholipid hydroperoxide glutathione peroxidase gene for protection of host cells from lipid hydroperoxide-mediated injury," Biochemical and Biophysical Research Communications, vol. 219, no. 2, pp. 486-491, 1996.

[35] B. Mannervik, "The enzymes of glutathione metabolism: an overview," Biochemical Society Transactions, vol. 15, no. 4, pp. 717-718, 1987.

[36] A. Meister, "Glutathione metabolism and its selective modification," The Journal of Biological Chemistry, vol. 263, no. 33, pp. 17205-17208, 1988.

[37] H. Imai and Y. Nakagawa, "Regulatory and cytoprotective aspects of lipid hydroperoxide metabolism," Free Radical Biology and Medicine, vol. 34, no. 2, pp. 145-169, 2003.

[38] D. E. Handy and J. Loscalzo, "Redox regulation of mitochondrial function," Antioxidants \& Redox Signaling, vol. 16, no. 11, pp. 1323-1367, 2012.

[39] D. Furling, O. Ghribi, A. Lahsaini, M.-E. Mirault, and G. Massicotte, "Impairment of synaptic transmission by transient hypoxia in hippocampal slices: improved recovery in glutathione peroxidase transgenic mice," Proceedings of the National Academy of Sciences of the United States of America, vol. 97, no. 8, pp. 4351-4356, 2000.

[40] K. Venardos, G. Harrison, J. Headrick, and A. Perkins, "Effects of dietary selenium on glutathione peroxidase and thioredoxin reductase activity and recovery from cardiac ischemiareperfusion," Journal of Trace Elements in Medicine and Biology, vol. 18, no. 1, pp. 81-88, 2004.

[41] F. D. Suyatna, R. Djohan, A. Nafrialdi, and S. K. Suherman, "The antioxidant effects of curcumin on rat liver mitochondrial dysfunction induced by tert-butylhydroperoxide," Journal of Ecophysiology and Occupational Health, vol. 4, pp. 145-151, 2004.

[42] H.-J. Freisleben, "Free radicals and the antioxidant network," in Free Radical-Related Diseases and Antioxidants in Indonesia, 
H.-J. Freisleben and B. Deisinger, Eds., pp. 1-12, Gardez, Sankt Augustin, Germany, 1999.

[43] V. E. Kagan, E. A. Serbinova, T. Forte, G. Scita, and L. Packer, "Recycling of vitamin E in human low density lipoproteins," Journal of Lipid Research, vol. 33, no. 3, pp. 385-397, 1992.

[44] V. E. Kagan, H.-J. Freisleben, M. Tsuchiya, T. Forte, and L. Packer, "Generation of probucol radicals and their reduction by ascorbate and dihydrolipoic acid in human low density lipoproteins," Free Radical Research Communications, vol. 15, no. 5, pp. 265-276, 1991.

[45] H.-J. Freisleben and L. Packer, "Free-radical scavenging activities, interactions and recycling of antioxidants," Biochemical Society Transactions, vol. 21, no. 2, pp. 325-330, 1993.

[46] M.-H. Pan, T.-M. Huang, and J.-K. Lin, "Biotransformation of curcumin through reduction and glucuronidation in mice," Drug Metabolism and Disposition, vol. 27, no. 4, pp. 486-494, 1999.

[47] C. Fiorillo, M. Becatti, A. Pensalfini et al., "Curcumin protects cardiac cells against ischemia-reperfusion injury: effects on oxidative stress, NF- $\kappa \mathrm{B}$, and JNK pathways," Free Radical Biology and Medicine, vol. 45, no. 6, pp. 839-846, 2008.

[48] D. Hong, X. Zeng, W. Xu, J. Ma, Y. Tong, and Y. Chen, "Altered profiles of gene expression in curcumin-treated rats with experimentally induced myocardial infarction," Pharmacological Research, vol. 61, no. 2, pp. 142-148, 2010. 

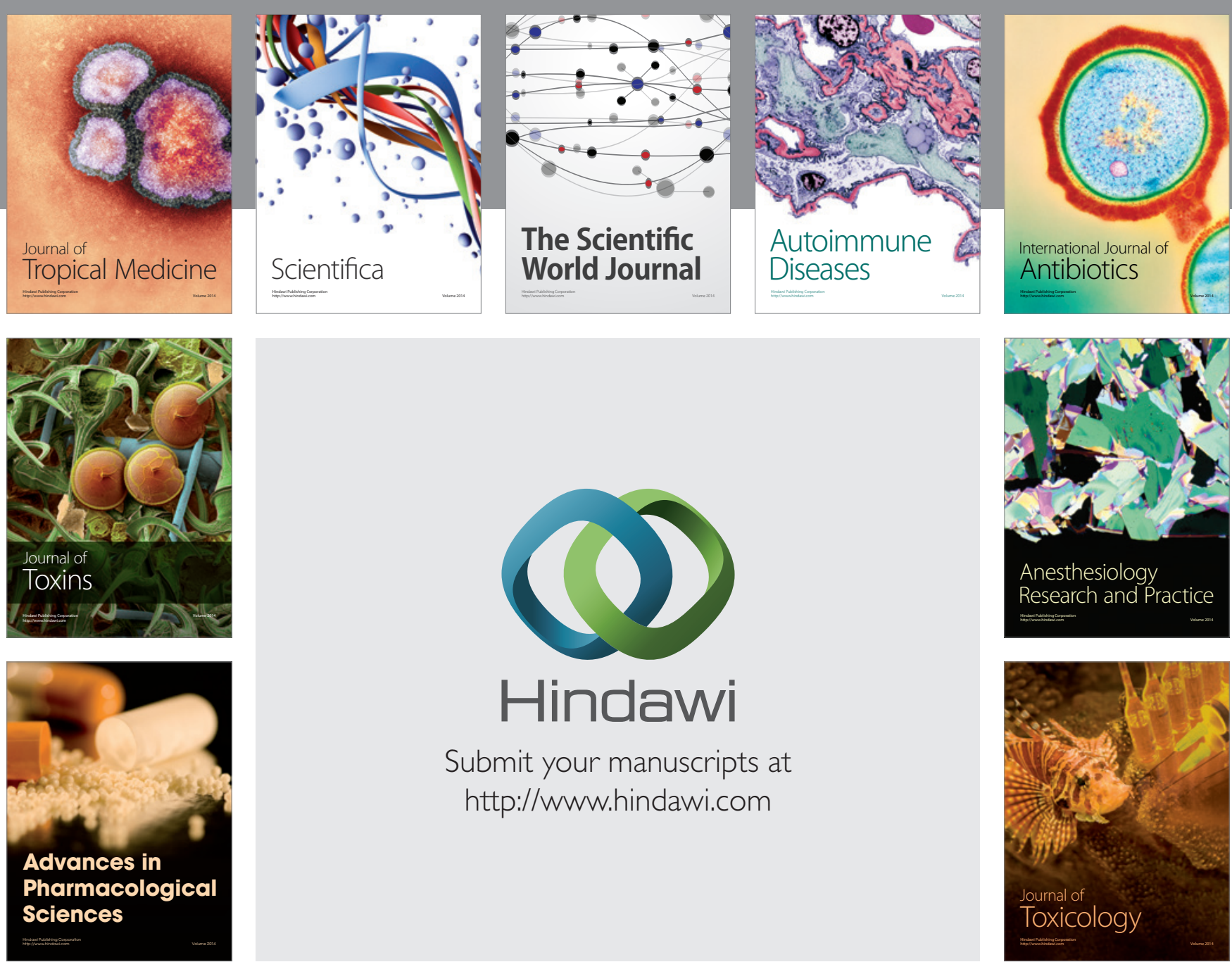

\section{Hindawi}

Submit your manuscripts at

http://www.hindawi.com
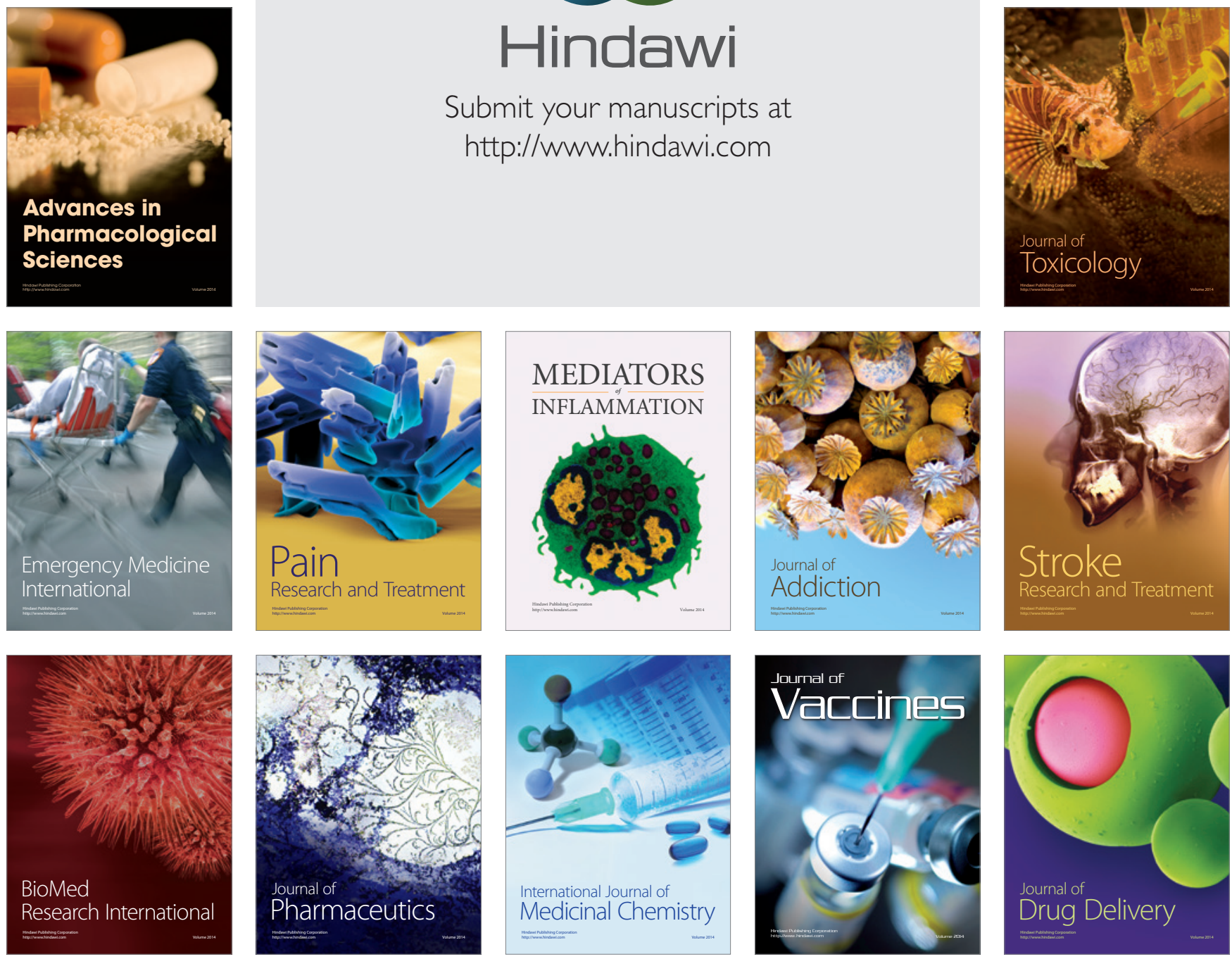